
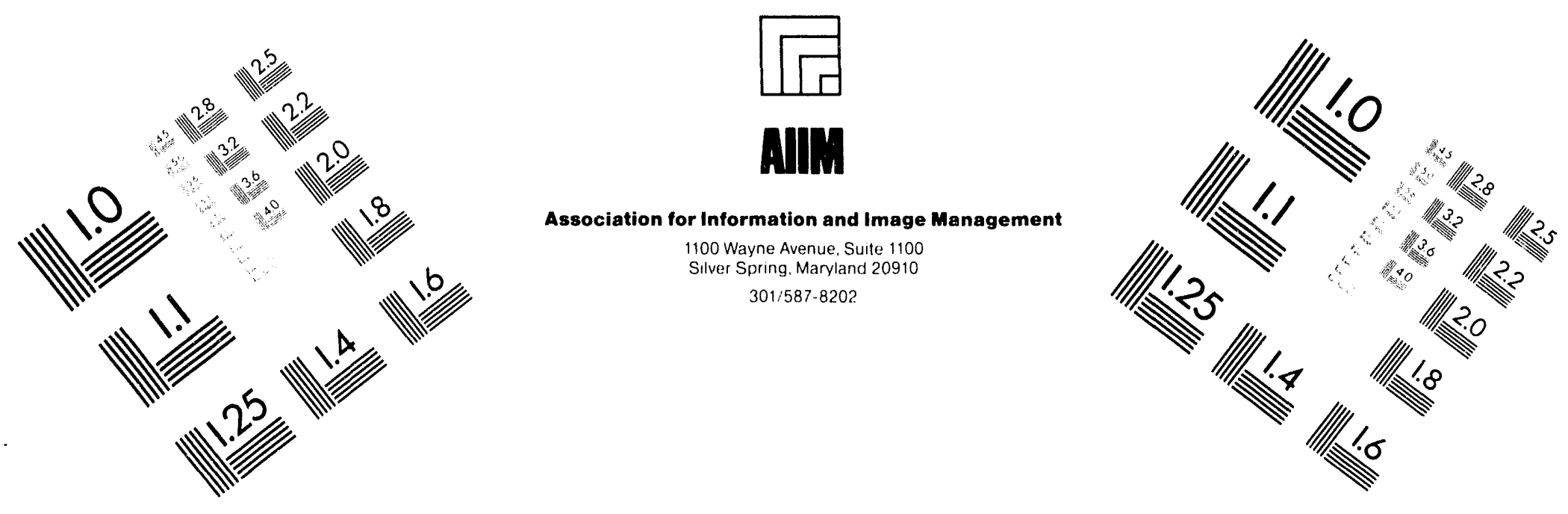

\title{
Centimeter
}

|

Inches
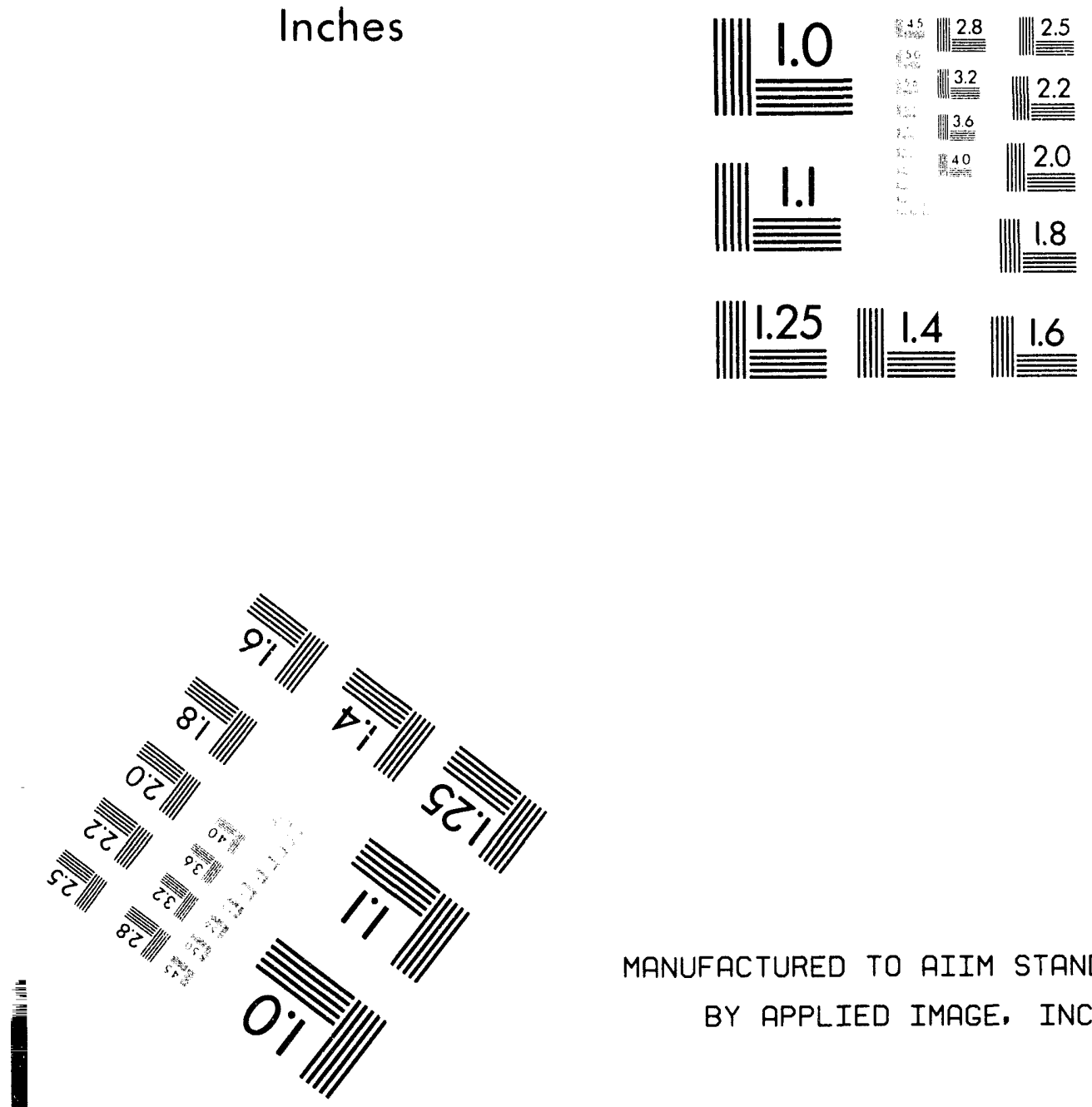

MANUFACTURED TO AIIM STANDARDS

BY APPLIED IMAGE, INC.

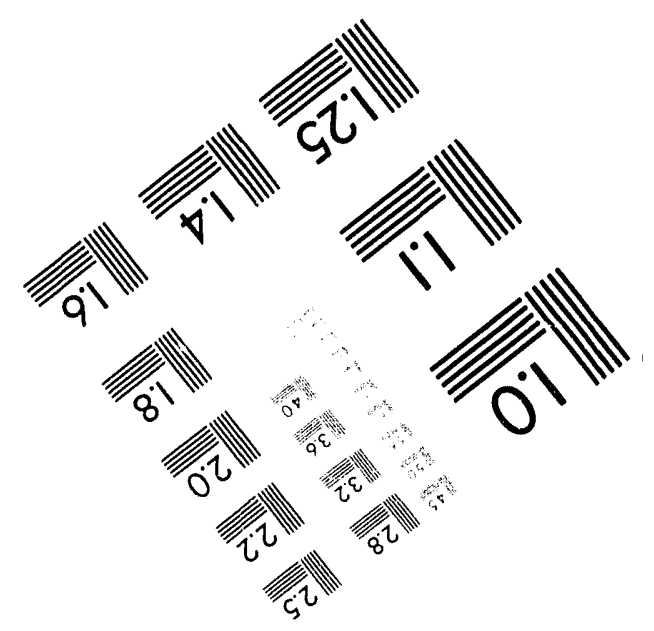



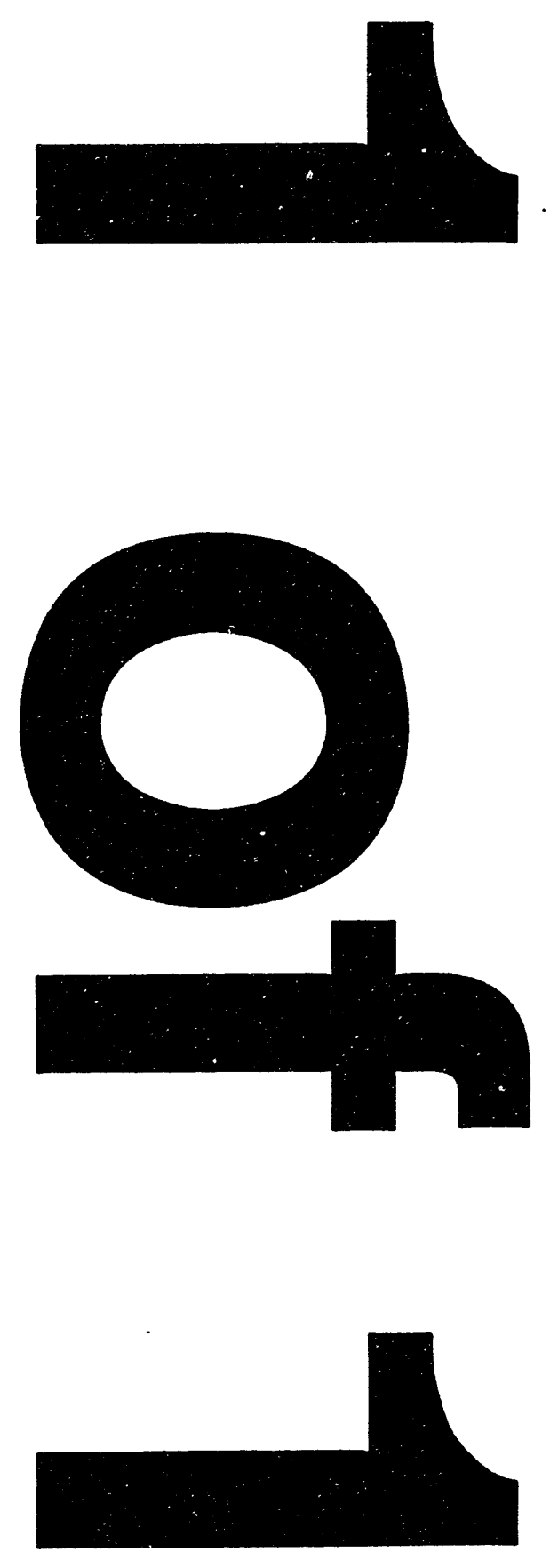


\section{RADIOECOLOGICAL IMPLICATIONS OF THE PAR POND DRAWDOWN}

by

H. Hickey

Westinghouse Savannah River Company

Savannah River Site

Aiken, South Carolina 29808

Whicker, F.W.

This paper was prepared in connection with work done under the above contract number with the U.S. Department of Energy. By acceptance of this paper, the publisher and/or recipient acknowledges the U. S. Government's right to retain a nonexclusive, royalty-tree license in and to any copyright covering this paper, along with the right to reproduce and to authorize others to reproduce all or part of the copyrighted paper. 


\section{DISCLAIMER}

This repor was prepared as 20 account of work sponsored by an agency of the United States Governmeat. Neither the United States Government nor any agency thereof, nor any of their employees. makes any warranty, express or implied, or assumes any legal liability or responsibility for the accuracy. completeness, or usefulaess of any information. apparatus, product, or process disclosed, or represents that its use would not infringe privately owned rights. Refereace bereia to any specific commercial product, process, or service by trade name, irademark. manufacturer, or otherwise does not necessarily constitute or imply its endorsement, recommendation, or favoriag by the United States Government or any agency thereof. The views, and opiaions of authors expressed berein do not necessarily state or reflect those of the United States Goverameat or any ageacy ithereof.

This report has been reproduced directly from the best available copy.

Available to DOE and DOE contractors from the Office of Scientific and Technical Information. P. O. Box 62. Oak Ridge. TN 37831: prices available from (615) $576-8401$.

Available to the public from the National Technical Information Service. U. S. Deparment of Commerce, S285 Port Royal Rd.. Springfield. VA 22161 


\title{
RADIOECOLOGICAL IMPLICATIONS OF THE PAR POND DRAWDOWN
}

\author{
By \\ F. Ward Whicker \\ Savannah River Ecology Laboratory \\ Drawer E \\ Aiken, SC 29802
}

December 5, 1991 


\title{
RADIOECOLOGICAL IMPLICATIONS OF THE PAR POND DRAWDOWN
}

\author{
By \\ F. Ward Whicker \\ Savannah River Ecology Laboratory \\ Drawer $\mathrm{E}$ \\ Aiken, SC 29802
}

December 5, 1991

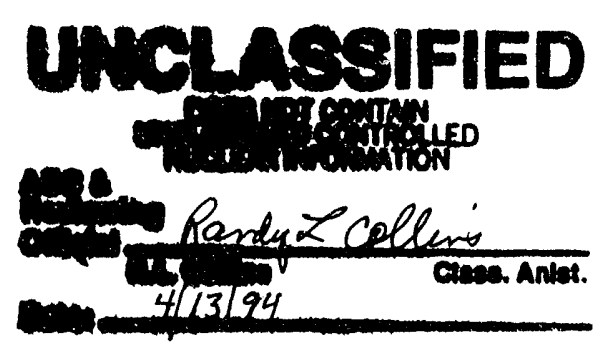




\section{RADIOECOLOGICAL IMPLICATIONS OF THE PAR POND DRAWDOWN}

\section{INTRODUCTION AND OBJECTIVES}

The drawdown of the Par Pond reservoir created dramatic alterations in this formerly stable lentic ecosystem. These alterations include impacts on water quality, sediment mobility, and aquatic vegetation and animal communities. In addition, the radiation environment at Par Pond has changed significantly because of the exposure of 137Cs-contaminated sediments and the appearance of new transport pathways to the terrestrial environment. In response to this situation, SREL was asked to study the radioecological implications of the reservoir drawdown. Specific objectives of the SREL radioecology studies include:

- Measurement of the gamma radiation exposure levels over the exposed sediments and determination of the causes of spatial variations.

- Determination of the ${ }^{137 C s}$ concentration versus depth profiles in sediment cores and interpretation of observed patterns.

- Provision of an independent estimate of the total $137 \mathrm{Cs}$ and $90 \mathrm{Sr}$ inventories in the sediments, based on the depth-integrated core profiles.

- Estimation of the magnitude and rate of sediment erosion and associated transport of radioactivity into the remaining impoundment.

- Documentation of any changes in the $137 \mathrm{Cs}$ and $90 \mathrm{Sr}$ concentrations in aquatic vegetation, invertebrates, and largemouth bass that may have been caused by the drawdown.

- Evaluation of the degree of $137 \mathrm{Cs}$ and $90 \mathrm{Sr}$ uptake by terrestrial plants and animals from the exposed areas of sediment.

- Contribution to general observations on the impacts of the drawdown on water quality, sediment dynamics, and biological phenomena. 
- Provision of a preliminary, worst-case radiation dose estimate for a person occupying and deriving sustenance from the contaminated lake bed.

\section{METHODS}

Measurements of the ambient gamma radiation exposure levels were made using a portable $5 \mathrm{~cm} \times 5 \mathrm{~cm} \mathrm{NaI}$ detector and integral mode scaler. This instrument was calibrated against an NIST- traceable $137 \mathrm{Cs}$ source, as well as a calibrated pressurized ion chamber (air-equivalent) at $\mathbf{3 1}$ different locations. Background radiation (cosmic and terrestrial) was estimated from measurements at 8 locations near Par Pond but in areas unaffected by the exposed sediments or other sources of contamination. The mean background exposure rate was subtracted from measurements over the exposed sediment to provide estimates of the net increase due to $137 \mathrm{Cs}$ contamination. Over 85 representative locations in all major areas of the reservoir have been selected for measurements to date. Sediment cores were extracted from over 64 exposed and underwater locations using an $18 \mathrm{~cm}^{2} \times 50 \mathrm{~cm}$ long coring device. Cores were cut into $1 \mathrm{~cm}$ thick sections for gamma spectroscopy using a $30 \%$ efficient reverse electrode germanium detector and standardized counting geometry. Sediment samples will also be analyzed for texture, organic matter, cation exchange capacity, $\mathrm{pH}$, and nutrient levels.

Sediment erosion is being measured monthly using sediment traps at three locations in Par Pond. The measurements will be expressed in dry $\mathrm{mg} / \mathrm{cm}^{2} / \mathrm{month}$ and this material will be analyzed for $137 \mathrm{Cs}$ and $90 \mathrm{Sr}$. Erosion patterns on the exposed lake bed are being qualitatively documented using photography and periodic observations.

Samples of aquatic and terrestrial vegetation, clams and mussels, and largemouth bass are being collected seasonally from representative areas throughout Par Pond. The wildlife survey portion of SREL's program is also providing feral pig 
tissues (muscle and bone) for analysis. All samples are being assayed for ${ }^{137 \mathrm{Cs}}$ using gamma spectroscopy. Samples will be submitted to a commercial laboratory for $90 \mathrm{Sr}$ analysis. Anecdotal observations and photographs are being taken to document the general environmental impacts of the drawdown.

A preliminary estimate of the worst-case radiation dose to a person that might live continuously on the exposed lake bed was made using actual data where available; otherwise parameters from the NCRP Commentary 3 Screening Model were employed. It was assumed that vegetables, meat, and milk were produced on the lake bed and that these foods were consumed throughout the year, with no credit taken for uncontaminated foods purchased commercially. Exposure pathways examined were external gamma exposure, ingestion, and inhalation. Radionuclides

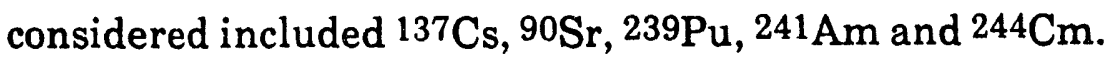

\section{RESULTS TO DATE}

\section{Gamma Radiation Exposure Levels}

Approximately 1300 acres of sediments have been exposed by the drawdown from 200 feet elevation to 181 feet. The entire area of exposed sediments has elevated radiation levels, although variations in both space and time are evident. The net exposure rates generally ranged from 4 to $11 \mu \mathrm{R} / \mathrm{hr}$, with an overall mean of approximately $8 \mu \mathrm{R} / \mathrm{hr}$ (Fig. 1). Readings in the Hot and North Ar, ns of Par Pond were typically 30 to $50 \%$ higher than those in West Arm. This patter a reflects the fact that contamination entered Par Pond at different times from both Hivt Arm and North Arm. Readings taken in October 1991 from the same locations surveyed two months earlier revealed an increase with time at all locations. On average, the increase was about $30 \%$. We believe the increase can be explained by observations that the sediments dried out considerably between August and October. This 
resulted in shrinking and cracking of the fine sediments and less water to attenuate the photons generated by $137 \mathrm{Cs}$ decay.

the

In addition to be modest differences in the gamma exposure rates between general areas of the reservoir, two finer-scale patterns were evident. One pattern relates to elevation, or the depth of the overlying water column prior to drawdown. Exposure levels above sediments that were in shallow water near shore prior to drawdown are generally low because wave action tended to prevent the buildup of fine sediments that contain most of the 137Cs. Exposure levels tend to increase over sediments that were covered by 5-15 feet of water. The macrophyte beds were most well-developed in this zone and it was shown previously in Pond B that dense, aquatic vegetation tends to produce a local buildup of radionuclides (Whicker et al. Ecological Monographs 60:471-496, 1990). If the reservoir were to be drawn down further than the 181 foot level, we would expect to encounter considerably elevated exposure levels because of the long term buildup of fine particulates in the quiescent, deeper areas. This expectation is borne out by our sediment core data and by the in-situ gamma spectroscopy measurements carried out by Bill Winn of Westinghouse Savannah River Company.

Another source of fine scale variability relates to topographic features. In most areas of exposed lake bed there are both natural and man-made undulations in the terrain which result in a complex mosaic of depressions and mounds. The mounds almost invariably consist of sand, with little or no buildup of fine organic and inorganic particles. Conversely, the depressions have accumulated the fine materials to thicknesses ranging from a few centirieters to over $50 \mathrm{~cm}$. The $137 \mathrm{Cs}$ content of the fine sediments is much greater than that of the sandy materials, hence the radiation exposure rates in depressions exceed those over sandy mounds (Fig. 2). 


\section{$\underline{137 \mathrm{Cs} \text { in Sediment Cores }}$}

To date, 12 of 64 cores sampled have been assayed for $137 \mathrm{Cs}$ in $1 \mathrm{~cm}$ depth increments, with core depths ranging from 16 to $38 \mathrm{~cm}$. Figure 3 illustrates the ${ }^{137 \mathrm{Cs}}$ profiles for six cores taken on the exposed lake bed; the data for six cores taken underwater are shown in Fig. 4. Virtually all the 137Cs is confined to the upper 30 $\mathrm{cm}$, although very low levels are measurable in all segments assayed below that depth. Each core is somewhat unique, both in terms of the maximum concentrations encountered and the depths where the peak levels occur. Most cores exhibit a single peak between 4 and $8 \mathrm{~cm}$, although a few have two distinct peaks. One such core (CP23) had distinct peaks at the 10 and $21 \mathrm{~cm}$ depths. One core exhibited the maximum concentration in the $0-1 \mathrm{~cm}$ horizon. A "composite" core, calculated as the mean concentration in each horizon from all cores assayed is shown in Fig. 5. The peak of the composite occurs at a depth of $5 \mathrm{~cm}$. The mean concentration in the upper $10 \mathrm{~cm}$ is approximately $100 \mathrm{pCi} / \mathrm{g}$ dry weight as compared to approximately $400 \mathrm{pCi} / \mathrm{g}$ dry weight for Pond B sediments averaged over the top $10 \mathrm{~cm}$.

The total $137 \mathrm{Cs}$ in each core (in $\mathrm{pCi} / \mathrm{cm}^{2}$ ) was estimated by summing the quantities in each depth increment (Table 1). The quantities ranged from 49 to nearly $1,900 \mathrm{pCi} / \mathrm{cm}^{2}$. This variation reflects general location differences as well as the texture of the material in the upper $10 \mathrm{~cm}$ of the cores. Those cores of sandy texture throughout were low and those with fine- textured serliment in the upper layers were higher. The overall mean ( $\pm 1 \mathrm{se}$ ) was $538 \pm 1 \in 7 \mathrm{pCi} / \mathrm{cm}^{2}$, but this is probably not representative of the reservoir as a whole because of the disproportionate number of samples from the more contaminated hot arm. An overall area-weighted mean, calculated as the mean of the means for specific areas, was judged to be more representative for the entire reservoir. This value was 387 $\mathrm{pCi} / \mathrm{cm}^{2}$, which scales to about $44 \mathrm{Ci}$ for the total exposed plus water filled portions of the reservoir, based on an area estimate of $1.13 \times 1011 \mathrm{~cm}^{2}$. This estimate presently 
has an uncertainty ( $1 \mathrm{se} / \mathrm{mean}$ ) of about $50 \%$ due to the limited number of processed cores.

\section{apesition \\ Sediment,Rates}

Sediment traps were placed in the reservoir on $11 / 22 / 91$. Therefore, no estimates are available at this time. However, visible sediment has accumulated in just a few days, indicating that measurable sediment transport is occurring.

\section{Cs Concentrations in Aquatic and Terrestrial Organisms}

Just prior to the start of the Par Pond drawdown, 19 largemouth bass were collected from various representative areas of the reservoir. To date, 5 muscle samples have been assayed for $137 \mathrm{Cs}$. The mean value ( $\pm 1 \mathrm{se}$ ) was $8.8( \pm 1.0) \mathrm{pCi} / \mathrm{g}$ wet tissue. This value may be compared with a mean value of $12.3 \mathrm{pCi} / \mathrm{g}$ for largemouth bass in Par Pond in 1978 (Alberts et al. 1979 Annual Report, SREL). This reflects an effective ecological half time of 27 years, a value in excellent agreement with the 28 year half time estimated for Pond B (Whicker et al. Ecological Monographs 60:471-496, 1990). The mear ( \pm 1 se) 1991 value for 6 largemouth bass from Pond B was 140 ( \pm 6$) \mathrm{pCi} / \mathrm{g}$ wet tissue, a value 16 times that for Par Pond. The ratio of 16 for Pond B bass to Par Pond bass reflects enhanced bioconcentration mechanisms, since the ratio of Pond B to Par Pond sediments is only about 4 . The nutrient-poor status of Pond B can account for the enhanced 137Cs concentrations in its biota. We hypothesize that Par Pond bass will increase in $137 \mathrm{Cs}$ levels if the water chemistry becomes more similar to that of ground water seepage, as is the case for Pond B.

Thirty-two samples of vegetation growing in the water or on the exposed sediments have been collected to date. Samples of the $0-8 \mathrm{~cm}$ sediment horizon were taken from the rooting zone of the 18 samples taken on exposed areas to enable 
calculation of a concentration ratio. Five species were represented by the exposed lake bed collections, while 7 species are represented by the collections in water. The mean ( \pm 1 se) $137 \mathrm{Cs}$ content of 19 macrophyte samples growing in water was $19 \pm 8$ $\mathrm{pCi} / \mathrm{g}$ dry weight. The mean ( $\pm 1 \mathrm{se}$ ) of 18 vegetation samples from the exposed lake bed was $61 \pm 11 \mathrm{pCi} / \mathrm{g}$ dry. Species means ranged from $2 \mathrm{pCi} / \mathrm{g}$ dry for Typha latifolia to $112 \mathrm{pCi} / \mathrm{g}$ dry for Cyperus erythrorhizos. The value for Cyperus produces a plant/soil concentration ratio of about 1.0 , which is considerably higher than values typically used in dose assessment models. Such values are typically less than 0.03 . High 137 Cs uptake by plants growing on sandy, coastal plain soils would be expected, based on data from other studies.

\section{General Observations on Environmental Impacts}

The water quality of the reservoir appears to have been impacted by the drawdown. The most noticeable effect is on turbidity, which has increased as a result of sediment resuspension and runoff during rainstorm events. In the past, Secchi transparency of about $2.5 \mathrm{~m}$ has been reported (Tilly, USERDA Symposium Series, CONF-740513, 1975). Our Secchi measurements during October have averaged only $1.3 \mathrm{~m}$. We observed much lower transparency after rainfall events, but did not have the opportunity to make quantitative measurements. At present, we plan to make such measurements monthly and aîter storm events.

The sediments have dried and cracked in all but the bare, sandy areas or wet drainage areas. Significant erosion has been documented following rainstorms. In some areas, erosion gullies over 1 foot deep have been cut. Much of this material has been transported to the remaining impoundment. Shoreline erosion is substantial in many areas exposed to wave action; bank-undercutting is evident in local areas. No visual resuspension in to the airstream has been observed. 
The macrophyie beds have been devastated. Some important species, such as ellgrass and water lilies, appear to have been eliminated altogether. In some wet areas, cattails, lotus, and spike rush are attempting to recolonize the shoreline. Occasional plants can be found in shallow water, such as watermilfoil, coontail, lotus and Bacopa. However, they are extremely sparse and are not adequate to provide effective shelter for small fish or to retard sediment resuspension.

The impacts of the drawdown on freshwater mussels and clams are dramatic. The remains of these organisms are evident in virtually all exposed areas. However, live individuals can still be found in shallow water. We believe there was also a dramatic decline in the abundance of many aquatic insects as a result of the drawdown and resulting loss of macrophytes.

Although no massive fish kills have been observed, there is clear evidence of ongoing mortality. Casual observations indicate moderate numbers of medium-sized fish such as perch, bluegill, crappie, small bass and carp that have recently died. Efficient scavenging by alligators and birds tends to mask the extent of the mortality, but simple calculations suggest the possibility of over 100,000 deaths since the drawdown began. We believe stress associated with the loss of food and shelter and chasing by large predatory fish may explain such mortality. The drying of pools has also led to dessication of stranded fish in several locations. The loss of littoral habitat has exposed baitfish stocks to heavy predation by larger fish and wading birds. It is not yet clear whether this will cause some degree of starvation in the larger predatory fish next year, but this possibility seems likely.

\section{Preliminary Dose Estimate}

A preliminary dose estimate for a person that might live on and derive sustenance from the Par Pond lake bed was conducted with the simplified NCRP screening method and conservative parameters (Table 2). The radionuclide 
concentrations in the upper $10 \mathrm{~cm}$ of sediment were used as the starting point of the calculations. The $137 \mathrm{Cs}$ value was derived from our recent measurements, whereas the transuranic values were measured by Alberts et $\underline{\text { al. }} 1986$ (J. Env. Radioactivity 3:249-271). The 90Sr value was scaled from Pond B measurements (Whicker et al. 1990 Ecol. Monogr. 60:471-496).

The NCRP model calculation for $137 \mathrm{Cs}$ in beef was only $3.6 \mathrm{pCi} / \mathrm{g}$ wet tissue, while actual recent measurements of pig muscle from the area yielded values of about $18 \mathrm{pCi} / \mathrm{g}$. Therefore, the latter value was used in the calculation of dose. The resuspension value used $\left(10^{-6} \mathrm{~m}^{-1}\right)$ was arbitrary, but judged to be conservative. The external dose factor used $\left(0.3 \mathrm{mrem} / \mathrm{yr}\right.$ per $\left.\mathrm{pCi} / \mathrm{cm}^{2}\right)$ was provided by Kocher 1983 (Radiological assessment, NUREG/CR-3332/ORNL-5966). This value yielded an exposure rate higher than actual measurements by a factor of about 1.7. However, the actual measurements were confined to exposed sediments at the 181 foot elevation. If the reservoir were completely drained, data indicate that mean exposure rates would be considerably higher. We therefore used the value provided by Kocher and the area-weighted mean $137 \mathrm{Cs}$ level of $387 \mathrm{pCi} / \mathrm{cm}^{2}$ (Table 1 ).

The estimated committed effective dose equivalents from subsisting on the lake bed for one year are shown in Table 3. Cesium-137 is clearly the dominant dose contributor. The external exposure and ingestion pathways are comparable; the inhalation pathway appears minor. The total value of $272 \mathrm{mrem} / \mathrm{yr}$ is well above the international guideline of $100 \mathrm{mrem} / \mathrm{yr}$ for continuous exposure of the general public. 


\section{EXECUTTVE SUMMARY}

The drawdown of the Par Pond reservoir has exposed approximately 1300 acres of sediments contaminated with $137 \mathrm{Cs}$ and other radionuclides. This has caused obvious radiological and environmental impacts, the most obvious and significant of which are enumerated below:

- Radiation exposure rates at 1 meter above the exposed lake bed average about $8 \mu \mathrm{R} / \mathrm{hr}$ above background. The Hot and North arms of the reservoir have $30-50 \%$ higher exposure rates than West Arm. Radiation levels have increased about $30 \%$ due to drying of the exposed sediments. Exposure rates vary with elevation and topography.

- Sediment cores indicate that nearly all the $137 \mathrm{Cs}$ activity is in the top 30 $\mathrm{cm}$, with peak concentrations tending to occur between the 4 and $8 \mathrm{~cm}$ depths. The mean concentration in the top $10 \mathrm{~cm}$ is about $100 \mathrm{pCi} / \mathrm{g}$ dry weight. The total quantity of $137 \mathrm{Cs}$ in sediment cores ranged from 60 to $1,900 \mathrm{pCi} / \mathrm{cm}^{2}$, with an area-weighted mean of $387 \mathrm{pCi} / \mathrm{cm}^{2}$. This value translates to a total inventory estimate of $44 \mathrm{Ci}$ for the entire reservoir. The highest sediment inventories appear to be in the areas still submerged at the 181 foot water level.

- Vegetation that has invaded the exposed sediments is taking up easurable quantities of $137 \mathrm{Cs}$. Feral pigs have been rooting on the exposed sediments and concentrations of 137Cs in their tissues are wellabove average levels for the site.

- The exposed sediments are undergoing significant erosion during heavy rainstorms. Shoreline erosion is also significant because of the lack of littoral vegetation. This has reduced the transparency of the water and is producing enhanced sedimentation in the remaining impoundment. 
- The macrophyte beds have been devastated, resulting in the loss of habitat critical to the maintenance of a stable and balanced biological community. Dramatic losses of freshwater invertebrates and small baitfish are evident. A loss of over 100,000 medium-sized fish representing at least 5 species may have occurred.

- A preliminary set of dose calculations indicates that a person subsisting on the unremediated, exposed sediments could receive a total annual effective dose equivalent of over 250 mrem from external exposure, ingestion and inhalation pathways. This value exceeds the international standard of 100 mrem/year for the public at large. 
Doe I
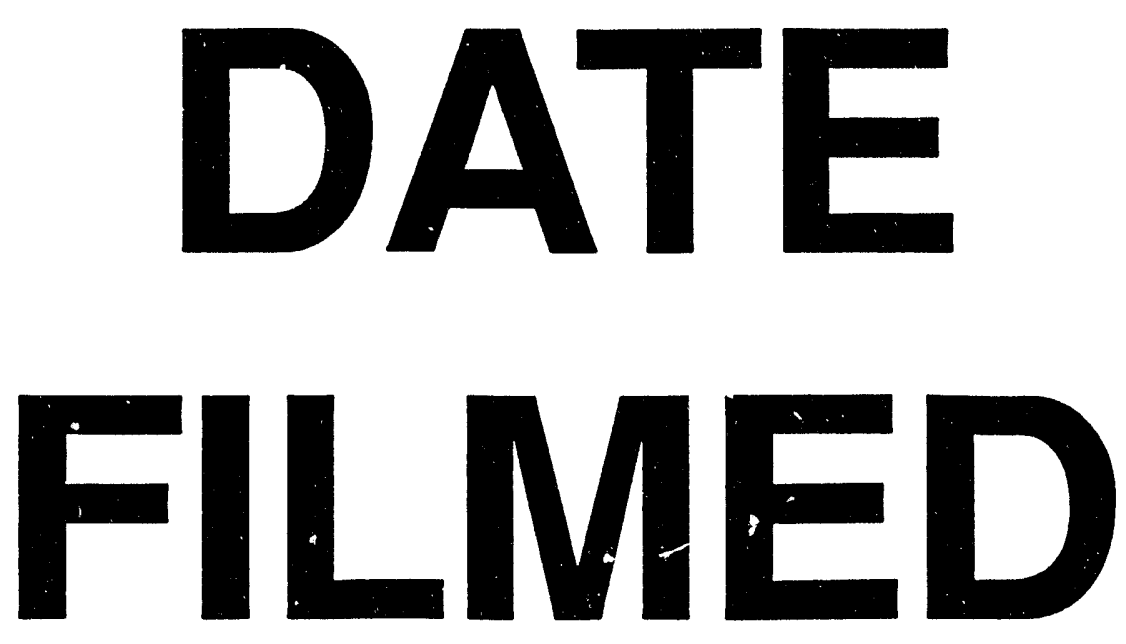

$$
8 / 18 / 94
$$
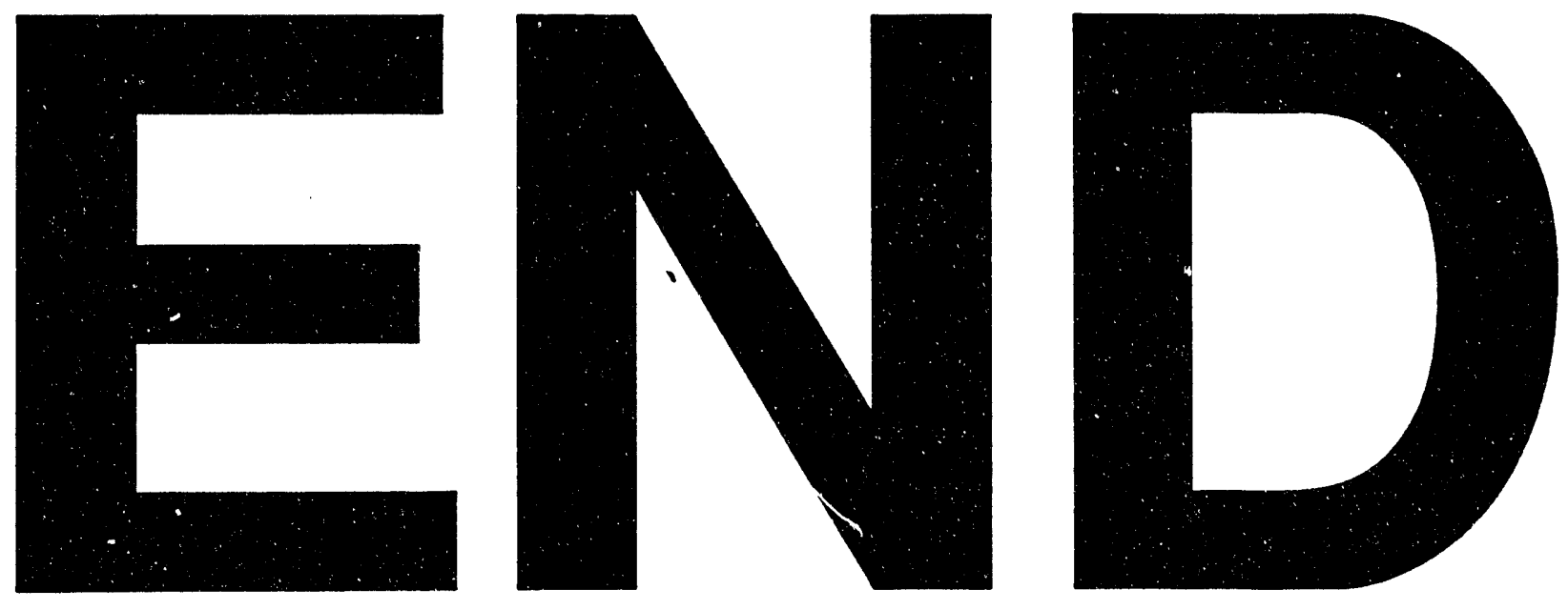
